\begin{abstract}
一論＼cjkstart文——(日本化学会誌，1990，（6）， p.655６61）
(C) 1990 The Chemical Society of Japan

\section{ジ-2-ピリジルエタンジオンの $\mathbf{n} \rightarrow \pi^{*}$ 遷移の性格}

(1989 年 12 月 27 日受理)

\author{
星 敏 彦*・大窪 潤** 小野 勲・渡邊誠一 \\ , 井上 廣 保 $^{* * *} \cdot$ 桜井忠光 ${ }^{* * *} \cdot$ 小林迪夫***
}

ジ-2-ピリジルエタンジオンの吸収スペクトルをエチルエーテル：イソペンタン：エタノールの 5 : $5: 2$ 混合溶媒 (以下 EPA と略記) 中室温就よび $101 \mathrm{~K}$ で測定し, ベンジル (ジフェニルェタンジオ ン）のスペクトルと比較した。また，ジ-2-ピリジルェタンジオンとその半分の $\pi$ 電子系をもつ 2-アセ チルピリジンの偏光吸収スペクトルを延伸高分子膜法により測定した。その結果たと劣ば，ジ-2-ピリ ジルエタンジオンの 320 430 nm にある振動構造をともなった非常に弱い吸収帯は二つの電子遷移か らなっており，その 0-0 遷移は 398 および $352.0 \mathrm{~nm}$ にあることがわかった。これら二つの遷移は いずれも酸素原子の $\mathrm{n}$ 軌道から $\pi^{*}$ 軌道への遷移である。二つの $\mathrm{n} \rightarrow \pi^{*}$ 遷移の分裂幅についての実測 值と $\mathrm{MO}$ 計算の比較から，ジ-2-ピリジルエタンジオンは溶液中で中央の C-C 結合のまわりに約 $80^{\circ}$ ねじれていると推定された。また，Configuration analysis の結果から，ジ-2-ピリジルェタンジオン の $398 \mathrm{~nm}$ 帯は二つの 2-アセチルピリジン骨格にそれぞれ局在化した $\mathrm{n} \rightarrow \pi^{*}$ 遷移であり, $352.0 \mathrm{~nm}$ 帯は一方の酸素原子の $\mathrm{n}$ 軌道から他方の $\pi$ 電子骨格への分子内電荷移動型の $\mathrm{n} \rightarrow \pi^{*}$ 遷移であることが わかった。
\end{abstract}

\section{1 緒言}

先に著者らは偏光吸収スペクトルの測定と MO 計算から, ヘ ンジル(ジフェニェタンジオン) の各電子遷移の性格, 電子構 造および配座について考察した1)。たとえば,ポリ(ビニルアルコ 一ル) (以下 PVA と略記する) 膜中 382 および $334 \mathrm{~nm}$ に観测 される非常に弱い带は $\mathrm{n} \rightarrow \pi^{*}$ (以後 $\mathrm{n} \pi^{*}$ 之表現する) 遷移による ものである。これら二つの $\mathrm{n} \pi^{*}$ 遷移の分裂幅についての実測值 と MO 計算值の比較から, 溶夜中でベンジルの中央の二つのカ ルボニル基間のねじれ角は約 $75^{\circ}$ であると推定された。このねじ れ角はX線回折の結果から得られた結晶状態での值 $\left(70^{\circ}\right)$ とよ 〈対応している1。このようにヘンンジルは中央の C-C 結合のまわ りでかなりねじれた構造をとっているために，一方のカルボニル 基の酸素原子の $\mathrm{n}$ 軌道の電子は他方のカルボニル基を含む $\pi$ 電子 系とかなり相互作用ができるようになる。このn轨道から $\pi^{*}$ 軌 道への遷移が $228 \mathrm{~nm}$ に観測された2)。

単結晶法による $20 \mathrm{~K}$ での偏光吸収スペクトルによると， ジー 2-ピリジルェタンジオン(以下通俗名 $2,2^{\prime}$-ピリジルと記載する) は 320 400 nm の波長領域に二つの弱い電子帯をもち, その 0-0

青山学院大学理工学部, 157 東京都世田谷区千藏台

** 青山学院大学総合研究所理工学研究センター, 157 東京 都世田谷区干歳台

**** 神奈川大学工学部, 221 横浜市神奈川区六角橋

**** 長岡技術科学大学化学系, 940-21 長岡市上富岡町

1）星 敏产, 大䆶 潤, 川島健信, 飯島一正, 井上廣保, 桜井忠光, 日化, 1987, 1 .

2) C. J. Brown, R. Sadanaga, Acta Crustallogr., 18, 158 (1965).
遷移は 401.0 および $350.0 \mathrm{~nm}$ にある3)。 $401.0 \mathrm{~nm}$ 帯は酸素原 子の孤立電子対からの $\mathrm{n} \pi^{*}$ 遷移に, $350.0 \mathrm{~nm}$ 帯は窒素原子によ る $\mathrm{n} \pi^{*}$ 帯に帰属されている ${ }^{3)}$ 。一般に垤素原子による $\mathrm{n} \pi^{*}$ 帯は アルコールなどの極性溶媒中では酸素原子の場合と異なり大きく 青方偏移し, 隣接する強い $\pi \pi^{*}$ 帯に隠され, 観測されない場合が 多い4。2,2'ピリジルの場合, $350.0 \mathrm{~nm}$ に対応する帯はエタ〉 ール中でも $340 \mathrm{~nm}$ 付近に観測されている3)。このよらなことか ら $350 \mathrm{~nm}$ 帯を窒素原子が関与した $\mathrm{n} \pi *$ 遷移に帰属するのは困 難であると思われる。

本研究では，2,2'-ピリジルについて延伸高分子膜法による偏 光吸収スペクトルの測定, 吸収スペクトルの溶媒効果, MO 計算 の結果などから, この化合物の電子遷移の性格, 電子構造, 立体 配座などについて考察する。

\section{2 実験}

2,2'ピリジルは市肘品 (Aldrich Chemical Company, Inc.) をエタノールから 3 回再結晶した。2-アセチルピリジン (和光純 薬工業株式会社製) は減圧蒸留 $\left(85^{\circ} \mathrm{C} / 20 \mathrm{~Pa}\right)$ により精製した。 $\mathrm{EPA}$ (ジェチルェーテル : イソペンタン : エタノール =5 : $5: 2$ ) 㓮珄溶媒の作成に用いたジェチルエーテルおよびインペンタンは 水酸化ナトリウムを加觉て還流し，金属ナトリウムを用いて脱水 した後, 蒸留した。エタノールは市販品（和光純薬工業株式会社 製, 試薬特級)をとのまま用いた。試料を含む PVA 膜は文献記 载の方法により作製しだ1。

3) S. C. Bera, R. K. Mukherjee, D. Mukherjee, M. Chowdhury, J. Chem. Phys., 55, .5826(1971).

4) S. F. Mason, J. Chem. Soc., 1959, 1247. 
吸収スペクトルの測定には島津 UV-360 形自記分光光度計を 用いた。低温での偏光吸収スペクトルの測定は文献記载の方法に したがっだ)。

\section{MO 計 算}

MO 計算には同一平面上にない $\pi$ 電子系間の相互作用も考虑 できるように拡張した PPP 法を用いだ)。すなわち, 互いに直交 した $\pi$-電子系間および $\pi$-と n-電子系間の相互作用は, Fock お。 よび配置間相互作用の行列要素のなかに電子間の反発の項として 考慮している。原子価状態での炭素および酸素原子のイオン化ポ テンシャル $\left(I_{\mathrm{p}}(\mathrm{r})\right)$ および電子親和力 $\left(E_{\mathrm{a}}(\mathrm{r})\right)$ には, つぎの 值を用いた。 $I_{\mathrm{p}}(\mathrm{C})=11.22 \mathrm{eV}, I_{\mathrm{p}}(\mathrm{O})=17.32 ， E_{\mathrm{a}}(\mathrm{C})=0.62$ $\mathrm{eV}, E_{\mathrm{B}}(\mathrm{O})=2.65 \mathrm{eV}$ 。共鳴積分の值は SCF 計算のたびに, 西 本-Forster の式により求めだ)。配置間の相互作用はすべての一 電子励起配置について考慮した。

\section{4 結果および考察}

4.1 EPA 中における 2,2'-ピリジルの電子吸収スペクトル EPA 中室温および $101 \mathrm{~K}$ における 2,2'ピリジルの吸収スペ クトルを図 1 に示す。なお，この図には比較のため同じ条件で測 定したベンジルの吸収スペクトルも示した。室温でのピリジル の吸収スペクトルは 300 430 nm にかけての弱い吸収帯 $(\varepsilon=$ 100〜200) と 200〜300 nm にかけての強い吸收帯 $(\varepsilon \geqq 10000)$ か らなっている。前者は $\mathrm{n} \pi *$ 遷移に, 後者は $\pi \pi^{*}$ 遷移に帰属され

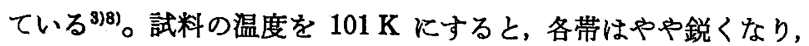
いくつかの新しい吸収帯が肩として現われる。長波長側の弱い吸 収帯のピークあるいは肩は $397,387.5,375,367,350.0$ および $340 \mathrm{~nm}$ にあり, 強い吸収帯のピークは 272.5 および $237.4 \mathrm{~nm}$ にある。Bera らは, $397 \mathrm{~nm}$ 帯を酸素原子の孤立電子対からの $\mathrm{n} \pi^{*}$ 遷移に, また $350 \mathrm{~nm}$ 帯を, シクロヘキサンおよびエタノー ル中室温で測定したベンジルの吸収スペクトルには対応する帯が 見られないことから，窒素原子の孤立電子対が関与した $\mathrm{n} \pi$ * 遷

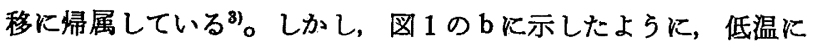
するとベンジルの吸収スペクトルにも 340 と $320 \mathrm{~nm}$ に新しい吸 収帯が明瞭に現われている。このことは, ピリジルの $350 \mathrm{~nm}$ 帯 が窒素原子に由来した $\mathrm{n} \pi$ * 僄移ではなく, 酸素原子による $\mathrm{n} \pi *$ 遷移である可能性が大きいことを意味している。先に述べたよう に空素原子が関与した $\mathrm{n} \pi^{*}$ 要移はアルュールなどの極性溶媒中 では大きく青方偏移し， $\pi \pi^{*}$ 帯に重なり，識別できなくなる。こ のことから考えても，ピリジルの $350 \mathrm{~nm}$ 帯を窒素原子による $\mathrm{n} \pi *$ 遷移に帰属するのは困難である。

\section{2 偏光吸収スペクトル}

図 2 に延伸 PVA 膜中 $101 \mathrm{~K}$ で測定した $2,2^{\prime}$ ーピリジルの偏光 吸収スペクトルを示す。また，因 3 には $2,2^{\prime}$ ーピリジルの半分の

5) T. Hoshi, H. Yamamoto, T. Miyauchi, S. Mori, M. Kobayashi, Y. Tanizaki, Ber.Bunsenges. Phys.Chem., $86,330(1982)$.

6) T. Hoshi, T. Kawashima, J. Okubo, M. Yamamoto, H. Inoue, J.Chem.Soc., Perkin Trans. 2, 1986, 1147.

7) K. Nishimoto, L.S. Forster, Theor. Chim. Acta, 3, 407(1965).

8) H. Inoue, K. Nagaya, J. Chem. Soc., Perkin Trans. $2,1983,1581$.

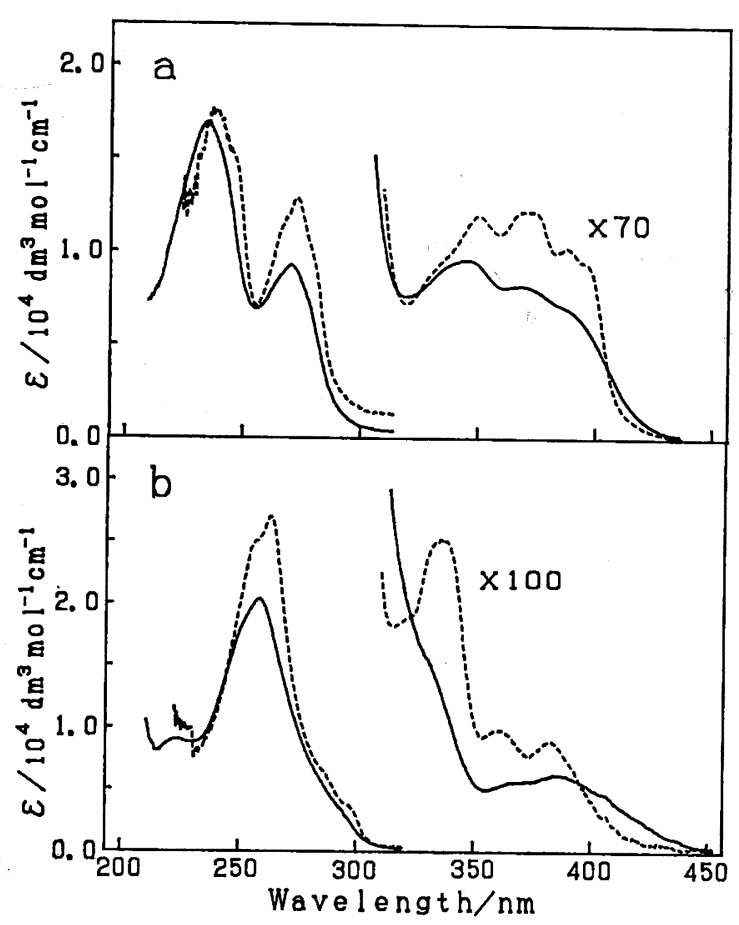

Fig. 1 Absorption spectra of 2,2'-pyridil (a) and benzil (b) in EPA at room temperature $(-)$ and $101 \mathrm{~K}(---)$

化学構造をもつ 2-アセチルピリジンの偏光吸収スペクトルを示 した。図中の $D_{\|}$および $D_{\perp}$ は膜の延伸方向と入射偏光の電 気べクトルがそれぞれ平行および垂直な場合の吸光度であり， $R_{\mathrm{d}}=D_{\|} / D_{\perp}$ である。 $\mathrm{EPA}$ 中 $101 \mathrm{~K}$ で測定した 2,2'ピリジル の 397, 375, 350.0, 272.5 および $237.4 \mathrm{~nm}$ 帯は, それぞれ延 伸 PVA 膜中 $101 \mathrm{~K}$ では 398, 374, 352.0, 271.9 および 237.9 $\mathrm{nm}$ に現われている。320 430 nm 領域にある $\mathrm{n} \pi *$ 帯の $R_{\mathrm{d}}$ 值 は, 398 および $374.4 \mathrm{~nm}$ 帯にくらべて $352.0 \mathrm{~nm}$ 帯領域でやや 小さくなっている。このことは, $352.0 \mathrm{~nm}$ 帯が他の二つの帯と は性格の異なる $\mathrm{n} \pi$ * 電子遥移によるものであることを意味して いる。

2-アセチルピリジンの PVA 膜中での吸収スペクトルは 229.5 および $270.0 \mathrm{~nm}$ に極大をもつ強い帯（これらの帯系の 0-0 遷 移はそれぞれ 239 および $278 \mathrm{~nm}$ 付近にあると思われる）と $324 \mathrm{~nm}$ に極大をもつ弱い帯からなっている。324 nm に吸収極大 をもつ带は 344 および $316 \mathrm{~nm}$ に肩をともなっている。(この帯系

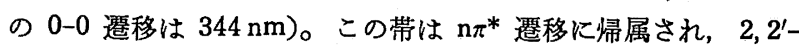
ピリジルの 320 430 nm 領域の $\mathrm{n} \pi^{*}$ 帯に対応している。2-アセ チルピリシンの $324 \mathrm{~nm}$ に吸収極大をもつ弱い $\mathrm{n} \pi *$ 帯の $R_{\mathrm{d}}$ 值 はほぼ一定の值を示している。このことから,この領域の $\mathrm{n} \pi *$ 帯 は, ピリジルの場合とは異なり， 1 種類の $\mathrm{n} \pi *$ 邆移によるもので あることがわかる。2-アセチルピリジンの場合にも，酸素あるい は窒素原子に由来した 2 種類の $\mathrm{n} \pi *$ 遷移の存在が考えられる。 しかし,この場合にも後で述べる MO 計算結果から, $324 \mathrm{~nm} に$ 吸収極大をもつ弱い帯は酸素原子が関与した $\mathrm{n} \pi *$ 透移に帰属さ れる。 


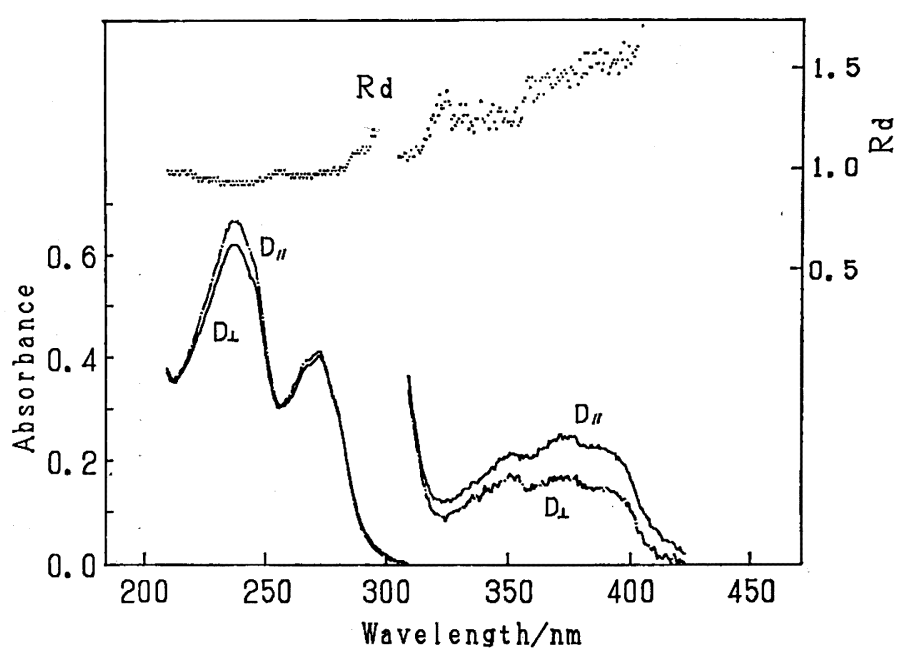

Fig. 2 The polarized absorption spectrum of $2,2^{\prime}$-pyridil in the stretched PVA film at $101 \mathrm{~K}$

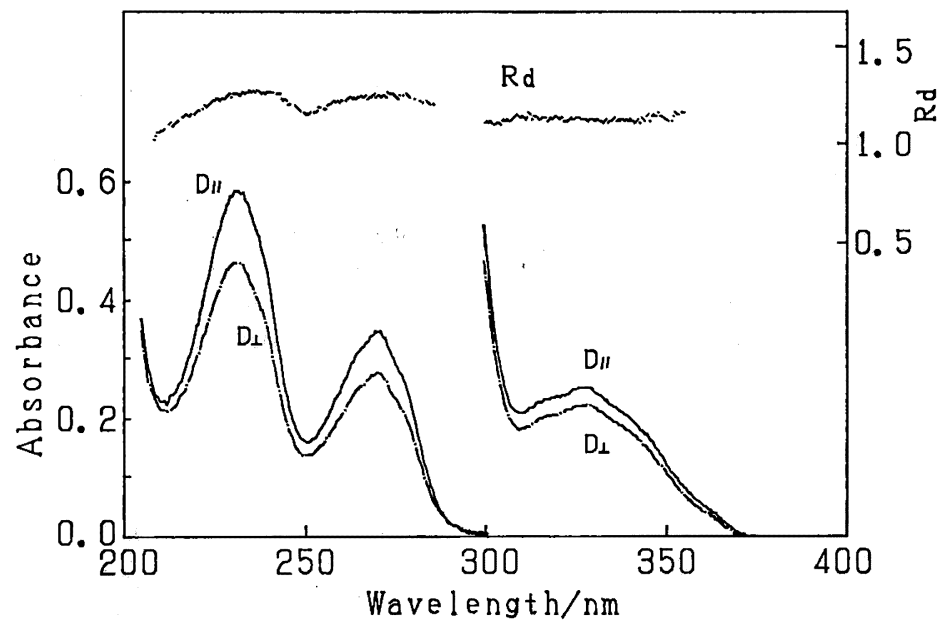

Fig. 3 The polarized absorption spectrum of 2-acetylpyridine in the stretched PVA film at $101 \mathrm{~K}$

\subsection{MO 計算による電子带の帰属}

2-アセチルピリジン特よび 2,2'ーピリジルの電子遷移の性格を 明らかにするために MO 計算を行った。表 1 に2-アセチルピリ ジンについて実測值と計算值を比較して示した。強度と波長位置 から 2-アセチルピリジンの 344, 278 拈よび $239 \mathrm{~nm}$ 帯が, それ ぞれ計算による $\mathrm{S}_{1} \leftarrow \mathrm{S}_{0}, \mathrm{~S}_{3} \leftarrow \mathrm{S}_{0}$ および $\mathrm{S}_{4} \leftarrow \mathrm{S}_{0}$ 遷移に州属され ることは明らかである。各電子遷移に対応与る励起状態の全波動 関数は次式で表される。

$$
\begin{aligned}
& \Psi_{1}=0.897 \chi_{5,7}+0.415 \chi_{6,8}+\cdots \cdots \\
& \Psi_{2}=0.810 \chi_{6,7}-0.540 \chi_{6,8}+\cdots \cdots \\
& \Psi_{8}=0.456 \chi_{3,7}+0.677 \chi_{4,7}-0.459 \chi_{4,8}+\cdots \cdots \\
& \Psi_{4}=0.493 \chi_{3,7}-0.694 \chi_{4,7}-0.497 \chi_{4,8}+\cdots \cdots
\end{aligned}
$$

この式で $\chi_{1, j}$ は $\mathrm{i}$ 番目の被占軌道から $\mathrm{j}$ 番目の空軌道に 1 個の 電子が励起した配置の波動関数である。また，この波動関数に関
Table 1 Calculated and observed transition energies and intensities for 2-acetylpyridine

\begin{tabular}{lccllc} 
& \multicolumn{2}{c}{$\begin{array}{c}\text { Transition energy } \\
\text { (nm) }\end{array}$} & & \multicolumn{2}{c}{ Intensity } \\
\cline { 2 - 3 } \cline { 5 - 6 } & Calc. & Obs. $^{a)}$ & & Calc. ${ }^{b)}$ & Obs. ${ }^{c)}$ \\
\hline $\mathrm{S}_{1}\left(\mathrm{n}_{0} \pi^{*}\right)^{e)}$ & 377.0 & 344 & & Forb. ${ }^{d)}$ & 10 \\
$\mathrm{~S}_{2}\left(\mathrm{n}_{\mathrm{N}} \pi^{*}\right)^{f)}$ & 315.8 & & & Forb. & \\
$\mathrm{S}_{3}\left(\pi \pi^{*}\right)$ & 285.2 & 278 & & 0.07721 & 3480 \\
$\mathrm{~S}_{4}\left(\pi \pi^{*}\right)$ & 246.6 & 239 & & 0.38730 & 7866 \\
$\mathrm{~S}_{5}\left(\pi \pi^{*}\right)$ & 232.6 & & & Forb. & \\
$\mathrm{S}_{6}\left(\pi \pi^{*}\right)$ & 205.1 & & 0.57739 &
\end{tabular}

a) Observed in cyclohexane.

b) Oscillator strength.

c) Molar absorptivity $\left(\mathrm{dm}^{3} \cdot \mathrm{mol}^{-1} \cdot \mathrm{cm}^{-1}\right)$ observed in cyclohexane.

d) Forbidden.

$e$ ) or $f$ ) The $n \pi^{*}$ transition from the n-orbital of the oxygen (or nitrogen) atom. 
Occupied orbitals Vacant orbitals<smiles>CC(C)C1CC2COC1O2</smiles><smiles>CC(C)C1CCCCO1</smiles><smiles>CC(CO)C1CCCCC1</smiles><smiles>CC(C)C1CCCCC1=O</smiles>

Fig. 4 Diagrammatic representations of MO's of 2-acetylpyridine

The radii of the circles are proportional to the magnitydes of $\mathrm{AO}$ coefficient, and the open and the closed circles represent the sign of the coefficients

与する MO を図式的に図 4 に示した。実測の $344 \mathrm{~nm}$ 帯に対応 する励起状態の波動関数 $\Psi_{1}$ の主寄与項は $\chi_{5,7}$ であり，これは MO $\phi_{5}$ から $\phi_{7}$ への励起に対応している。したがって, $344 \mathrm{~nm}$ 帯は酸素原子の $\mathrm{n}$ 軌道から $\pi^{*}$ 軌道への遷移であるとみなすこと ができる。また, $278 \mathrm{~nm}$ および $239 \mathrm{~nm}$ 帯に対応する励起状態の 波動関数はそれぞれ $\Psi_{3}$ および $\Psi_{4}$ であり, 両波動関数の主寄与 項はともに $\chi_{4,7}$ である。したがって, 278 および $239 \mathrm{~nm}$ 帯は 分子全体に非局在化した $\pi \pi^{*}$ 遷移である。計算による第二励起 状態の波動関数 $\Psi_{2}$ の主寄与項は $\chi_{6,7}$ であり, この励起状態へ の遷移は窒素原子の $\mathrm{n}$ 軌道 $\left(\mathrm{MO} \phi_{6}\right)$ から $\pi^{*}$ 軌道 $\left(\mathrm{MO} \phi_{7}\right)$ へ の励起に対応している。この $\mathrm{n} \pi^{*}$ 遷移は実際には観測されてい ない。

ピリジルやベンジルなどのような $\alpha$-ジケトン類は, 通常平面 構造から大きくねじれている 中央の炭素一炭素結合のまわりのねじれ角 $(\theta)$ は, シス形の平面 構造から $83^{\circ}$ である ${ }^{10)}$ 。 $2,2^{\prime}$ ーピリジルの構造が溶液や PVA マ トリックス中でも結晶の場合と同じであるという証拠はないが, ここでは一応上の角度を用いて MO 計算を行った。その結果を 実湘值と比較して表 2 に示した。PVA 膜中の $398 \mathrm{~nm}$ 帯は計算

9) S.C. Bera, R. Mukherjee, M. Chowdhury, J. Chem. Phys., 51, 754(1969).

10) S. Hirokawa, T. Ashida, Acta Crystallogr., 14, 774 (1961).

11) D. J. Morantz, A. J. C. Wright, J. Chem. Phys., 54, 692(1971).

12) J.F.Arnett, S.P. McGlynn, J. Phys. Chem., 79, 626 (1975).

13) S. C. Biswas, R. K. Sen, Chem. Phys. Lett., 94, 415 (1983).

14) R. Debrath, S. C. Bera, ibid., 95, 339(1983).
Table 2 Calculated ${ }^{a)}$ and observed transition energies and intensities for 2,2'-pyridil

\begin{tabular}{|c|c|c|c|c|}
\hline & \multicolumn{2}{|c|}{$\begin{array}{c}\text { Transition energy } \\
\text { (nm) }\end{array}$} & \multicolumn{2}{|c|}{ Intensity } \\
\hline & Calc. & Obs. ${ }^{b 1}$ & Calc. ${ }^{c)}$ & Obs. ${ }^{d)}$ \\
\hline $\left.\mathrm{S}_{1}\left(\mathrm{n}_{0} \pi^{*}\right) f\right)$ & 375.8 & 398 & Forb.e) & 73 \\
\hline $\mathrm{S}_{2}\left(\mathrm{n}_{\mathrm{O}} \pi^{*}\right)$ & 375.8 & $(374.4)^{h)}$ & Forb. & \\
\hline $\mathrm{S}_{3}\left(\mathrm{n}_{0} \pi^{*}\right)$ & 345.8 & 352.0 & Forb. & 106 \\
\hline $\mathrm{S}_{4}\left(\mathrm{n}_{0} \pi^{*}\right)$ & 345.8 & $(340)^{h)}$ & Forb. & \\
\hline $\mathrm{S}_{5}\left(\mathrm{n}_{\mathrm{N}} \pi^{*}\right)^{g)}$ & 330.0 & & Forb. & \\
\hline $\mathrm{S}_{\mathrm{B}}\left(\mathrm{n}_{\mathrm{N}} \pi^{*}\right)$ & 330.0 & & Forb. & \\
\hline $\mathrm{S}_{7}\left(\mathrm{n}_{\mathrm{N}} \pi^{*}\right)$ & 297.4 & & Forb. & \\
\hline $\mathrm{S}_{8}\left(\mathrm{n}_{\mathrm{N}} \pi^{*}\right)$ & 297.4 & & Forb. & \\
\hline $\mathrm{S}_{9}\left(\pi \pi^{*}\right)$ & 287.8 & 271.9 & 0.13931 & 7950 \\
\hline $\mathrm{S}_{10}\left(\pi \pi^{*}\right)$ & 286.4 & & 0.08842 & \\
\hline $\mathrm{S}_{11}\left(\pi \pi^{*}\right)$ & 246.3 & 237.9 & 0.35449 & 13100 \\
\hline $\mathrm{S}_{12}\left(\pi \pi^{*}\right)$ & 245.0 & & 0.27222 & \\
\hline $\mathrm{S}_{13}\left(\mathrm{n}_{\mathrm{N}} \pi^{*}\right)$ & 237.0 & & Forb. & \\
\hline $\mathrm{S}_{14}\left(\mathrm{n}_{\mathrm{N}} \pi^{*}\right)$ & 237.0 & & Forb. & \\
\hline $\mathrm{S}_{15}\left(\mathrm{n}_{0} \pi^{*}\right)$ & 230.5 & & Forb. & \\
\hline $\mathrm{S}_{16}\left(\mathrm{n}_{0} \pi^{*}\right)$ & 230.5 & & Forb. & \\
\hline
\end{tabular}

a) In this calculation the torsion angle $(\theta)$ around the central $\mathrm{C}-\mathrm{C}$ bond is assumed to be $83^{\circ}$.

b) Observed in cyclohexane.

c) Oscillator strength.

d) Molar absorptivity $\left(\mathrm{dm}^{3} \cdot \mathrm{mol}^{-1} \cdot \mathrm{cm}^{-1}\right)$ observed in cyclohexane.

e) Forbidden.

$f$ ) or $g$ ) The $n \pi^{*}$ transition from the $n$-orbital of the oxygen (or nitrogen) atom.

h) Tentative assignment.

による縮重した $\mathrm{S}_{1} \leftarrow \mathrm{S}_{0} お$ よび $\mathrm{S}_{2} \leftarrow \mathrm{S}_{0}$ 遷移に, $352.0 \mathrm{~nm}$ 帯は $\mathrm{S}_{3} \leftarrow \mathrm{S}_{0}$ および $\mathrm{S}_{4} \leftarrow \mathrm{S}_{0}$ 遷移に㷌属される。また, $271.9 \mathrm{~nm}$ 帯は ほぼ縮重した $\mathrm{S}_{9} \leftarrow \mathrm{S}_{0}$ および $\mathrm{S}_{10} \leftarrow \mathrm{S}_{0}$ 遷移の重なりに, $237.9 \mathrm{~nm}$ 帯は $\mathrm{S}_{11} \leftarrow \mathrm{S}_{0}$ および $\mathrm{S}_{12} \leftarrow \mathrm{S}_{0}$ 遭移の重なりによるものと思われ る。 $374.4 \mathrm{~nm}$ 帯扣よび EPA 中 $101 \mathrm{~K} て ゙ 340 \mathrm{~nm}$ 付近に観測さ れた肩については二つの解釈が可能である。その一つは両帯がそ れぞれ 398 および $352.0 \mathrm{~nm}$ 帯の振動構造であるという解釈であ る。他の一つは, 398, 374.4, 352.0 抽よび $340 \mathrm{~nm}$ 帯は, それ ぞれ $\mathrm{S}_{0}$ から $\mathrm{S}_{1}, \mathrm{~S}_{2}, \mathrm{~S}_{3}$ および $\mathrm{S}_{4}$ への遷移に㷌属されるといら 解釈である。図 2 に示した $2,2^{\prime}$-ピリジルの偏光吸収スペクトル によると, この波長領域で $R_{\mathrm{d}}$ 值が大きく変化しているので, 後 者の可能性が大きいように思われる。

2,2'ーピリジルに中央の C-C 結合のまわりに回転した種々の 配座が考えられる。したがって，ねじれ角が $83^{\circ}$ 以外の場合の配 座についても MO 計算を行うことは非常に興味深いことである。 図 5 に代表的な立体配座についての MO 計算結果を実測值と比 較して示した。この眓から明らかなよらに, $\theta$ が $0^{\circ}$ (シス平面構 造) および $\theta=180^{\circ}$ (トランス平面構造) についての計算結果は 実测值を満足していない。すなわちこれらの構造を用いて計算 した場合には，第一および第二 $\mathrm{n} \pi *$ ，遷移は実測值と比較してい ちじるしく低ェネルギー側に, 第三および第四 $\mathrm{n} \pi *$ 遥移はいち じるしく高ェネルギー側に算出されている。 $\theta=90^{\circ}$ についての 計算結果では 2 種類の $\mathrm{n} \pi$ 遷移は $360 \mathrm{~nm}$ 付近に算出され, 実測 値をほほ満足している。しかし，その分裂幅は実測值よりもかな 


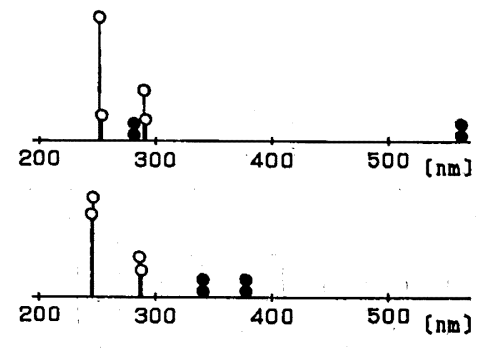

$\theta=0^{\circ}$
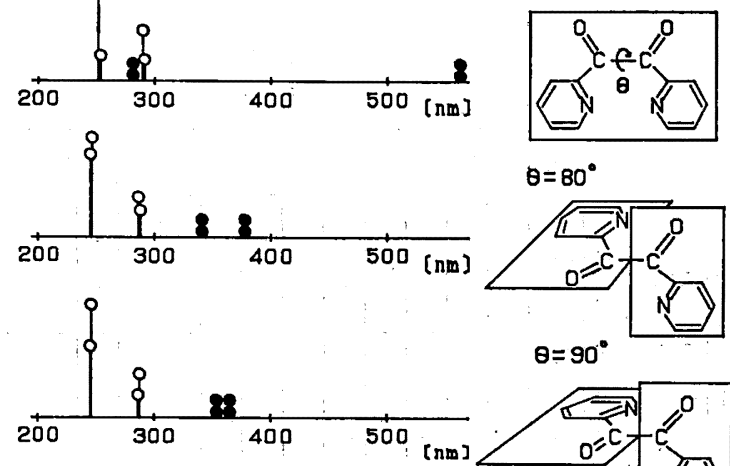

$\theta=90^{\circ}$
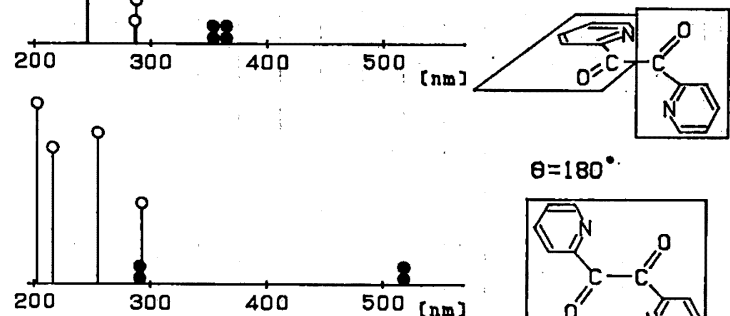

$\theta=180^{\circ}$
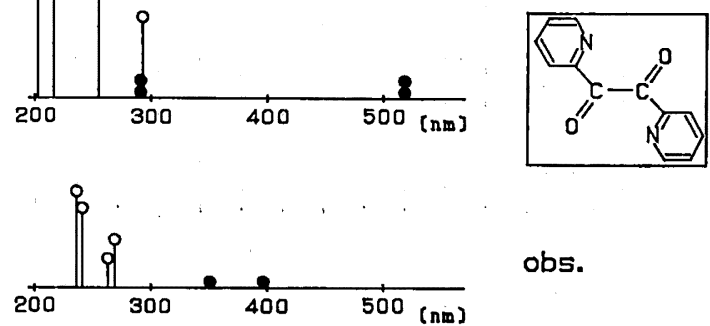

obs.

Fig. 5 Calculated transition energies and intensities for the four assumed structures of 2,2 -pyridil

$\theta$ : Torsion angle around the central $\mathrm{C}-\mathrm{C}$ bond axis

$O$ : Allowed $\pi \pi^{*}$ transition

: Forbidden $\mathrm{n} \pi^{*}$ transition

り小さくなっている。このことは実際の分子では, ねじれ角 $\theta$ が 90 からわずかにずれていることを示している。このことを確か めるために $\theta=90^{\circ}$ 近傍の配座について MO 計算を行い, 2 種 類の $\mathrm{n} \pi *$ 遷移の分裂幅と $\theta$ の関係を図 6 に示した。その結果, 実 測の分裂幅を満足する $\theta$ は $80^{\circ}$ (あるいは $100^{\circ}$ ) であった。 X線 回折の結果は $\theta=83^{\circ}$ であり, MO 計算の結果とよく一致してい る。このことは，2,2'ピリジルは溶液あるいはマトリックス中で

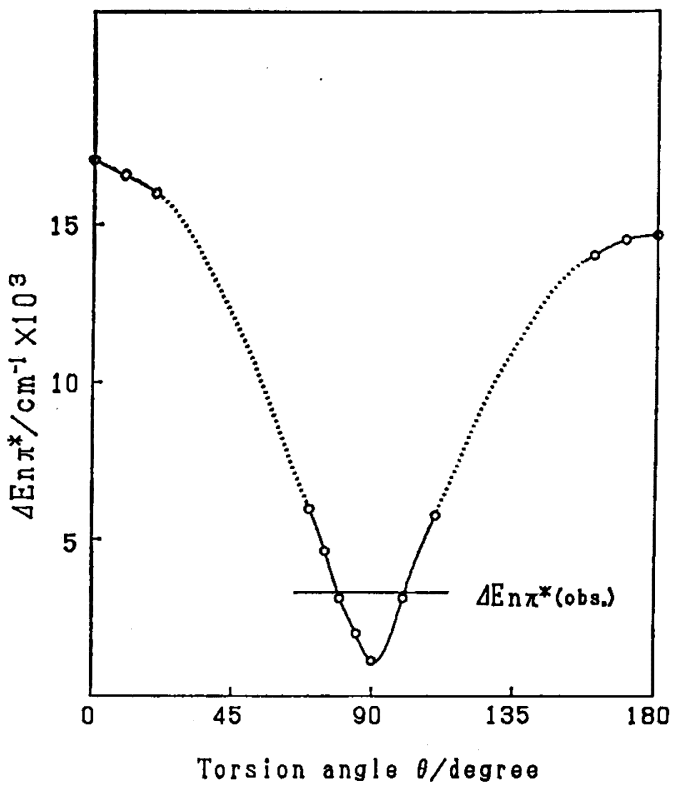

Fig. 6 Calculated energy seperations $\left(\Delta E_{n \pi^{*}}\right)$ between. the two kinds of $\mathrm{n} \pi^{*}$ transitions against the torsion angles $(\theta)$

も結晶の場合とほぼ同じ配座をとっていることを意味している。 先に述べた EPA 中低温におけるベンジルとピリジルの吸収ス ペクトルの比較によると, ピリジルの $300 \sim 430 \mathrm{~nm}$ にかけての 帯はすべて酸素原子が関与した $\mathrm{n} \pi^{*}$ 遷移によるものであると推 定される。この帰属の妥当珄を MO 計算の立場から検討した。 $\mathrm{n} \pi *$ 遷移に対応する励起状態の全波動関数 $\Psi_{1} \sim \Psi_{8}$ は次のように 表される。

$$
\begin{aligned}
& \Psi_{1}=0.916 \chi_{10.13}+\cdots \cdots \quad \Psi_{2}=-0.916 \chi_{9,18}+\cdots \cdots \\
& \Psi_{3}=0.920 \chi_{10,14}+\cdots \cdots \\
& \Psi_{5}=0.764 \chi_{12,13}-0.621 \chi_{12,14}+\cdots \cdots \\
& \Psi_{8}=-0.764 \chi_{11,13}-0.621 \chi_{11,14}+\cdots \cdots
\end{aligned}
$$

\section{Occupied orbitals Vacant orbitals}
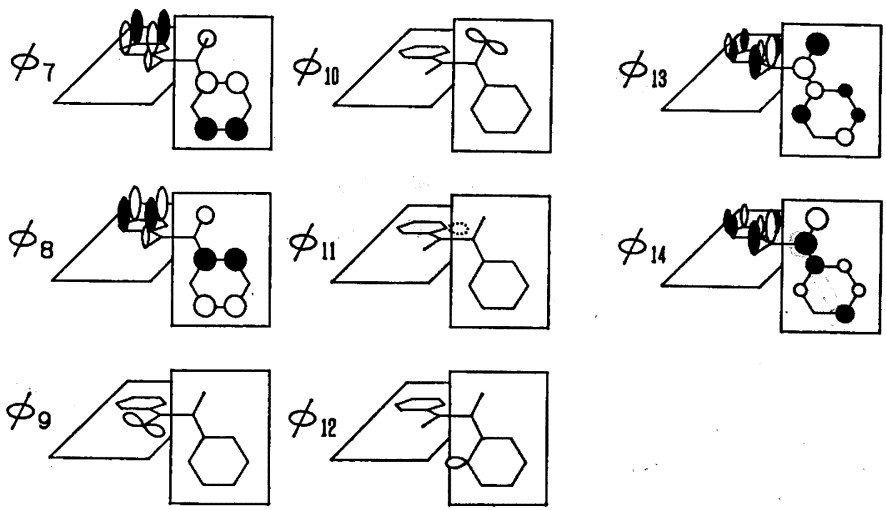

Fig. 7 Diagrammatic representations of MO's of 2,2'-pyridil

The radii of the circles are proportional to the magnitudes of AO coefficient, and the open and the closed circles represent the sign of the coefficients 


$$
\begin{aligned}
& \Psi_{7}=0.675 \chi_{11,14}-0.530 \chi_{11.13}+\cdots \cdots \\
& \Psi_{8}=-0.675 \chi_{12,14}-0.530 \chi_{12,13}+\cdots \cdots
\end{aligned}
$$

実測の $398 \mathrm{~nm}$ 帯は縮重した励起状態の波動関数 $\Psi_{1}$ および $\Psi_{2}$ に対応する。このらち, たと齐ば， $\Psi_{1}$ の主寄与項は $\chi_{10,13}$ であ

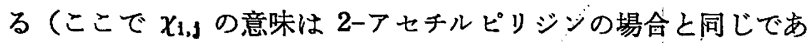
る)。MO $\phi_{10}$ は酸素原子の $\mathrm{n}$ 軌道であり， $\phi_{13}$ は分子全体に非局 在化した $\pi^{*}$ 軌道である (図 7 参照)。したがって， $\mathrm{S}_{1} \leftarrow \mathrm{S}_{0}$ 遷移 は酸素原子の $\mathrm{n}$ 軌道から $\pi^{*}$ : 軌道への遷移であることがわかる。 同様の議論から, $\mathrm{S}_{0}$ から $\mathrm{S}_{2}, \mathrm{~S}_{3}$ 扎よび $\mathrm{S}_{4}$ への遷移も酸素原子 が関与した $\mathrm{n} \pi *$ 遷移である。

$\Psi_{5}$ の主寄与項は $\chi_{12,18}$ 和よび $\chi_{12,14}$ である。 $\phi_{12}$ は窒素原子

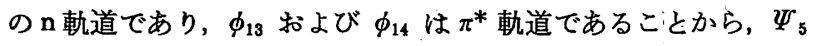
が関与する遷移は窒素原子が関係した $\mathrm{n} \pi *$ 遷移である。同様に $\Psi_{8}, \Psi_{7}$ および $\Psi_{8}$ は窒素原子の $\mathrm{n}$ 軌道から $\pi^{*}$ 軌道への励起に 対応している。これらの窒素原子が関与した $\mathrm{n} \pi *$ 䑁移は, 331 か ら $297 \mathrm{~nm}$ に算出され、これらの遷移は隣接した強い $\pi \pi^{*}$ 帯に 隠されてしまらものと思われる。上の MO 計算による $\mathrm{n} \pi *$ 遷移 の㷌属は，3.1 で述べた実験による $\mathrm{n} \pi$ *帯の帰属を完全に支持し ている。

\subsection{Configuration analysis による各電子蹥移の性格}

2, 2'-ピリジルの各電子遷移に 2-アセチルピリジンの電子遷 移，とくに $\mathrm{n}$ 軌道からの励起がどのように寄与しているかを知る ために Configuration analysis を行った ${ }^{15)}$ 。表 3 にその結果を示 した。この表で $\Psi_{G}$ および $\Psi_{1}$ は 2,2 -ピリジルの基底および励 起状態の全波動関数である。 $\Psi_{\mathrm{G}}{ }^{0}$ は 2-アセチルピリジン 1 (AP 1 と略記する) および 2 (AP 2 と略記する) の基底状態の波動関 数である。LE 1 および LE 2 はそれぞれ AP 1 および AP 2 内 での局在化励起を意味する。たとえば, $\Psi_{1}{ }^{0}\left(n_{0} \pi^{*}, L E 1\right)$ は AP 1 内での酸素原子の $\mathrm{n}$ 軌道から $\pi^{*}$ 軌道への励起配置の波動 関数であり, $\Psi_{2}{ }^{0}\left(\mathrm{n}_{\mathrm{N}} \pi^{*}, \mathrm{LE} 1\right)$ は窒素原子の $\mathrm{n}$ 軌道からの励起 に対応する波動関数である。また， $\Psi_{1}^{0}\left(\pi \pi^{*}\right.$, LE 1) は AP 1 内での局在化 $\pi \pi^{*}$ 励起配置の波動関数である。 $\Sigma \Psi \mathrm{n}_{\mathrm{O}} \pi^{*}$ (CT 1 ) は AP 1 の $\mathrm{n}$ 軌道から AP 2 の* 軌道への分子内電荷移動配置 の寄与の総和であり， $\Sigma \Psi \mathrm{n}_{\mathrm{O}} \pi^{*}(\mathrm{CT} 2)$ は CT 1 とは逆の分子内 電荷移動配置の寄与を意味する。

表 3から明らかなよらに2,2'ーピリジルの基底状態はほぼ100\% 二つの 2-アセチルピリシンの基底状態に対応している。 $398 \mathrm{~nm}$ に観測された $\pi^{*}$ 遷移に対応する $\Psi_{1}$ および $\Psi_{2}$ の主寄与項はそ れぞれ $\Psi_{1}{ }^{0}\left(\mathrm{n}_{\mathrm{O}} \pi^{*}, \mathrm{LE} 1\right)(69 \%)$ および $\Psi_{1}{ }^{0}\left(\mathrm{n}_{\mathrm{O}} \pi^{*}, \mathrm{LE} 2\right)(69 \%)$ である。したがって, $398 \mathrm{~nm}$ 帯は二つの 2-アセチルピリジン骨

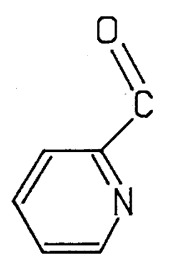

AP 1

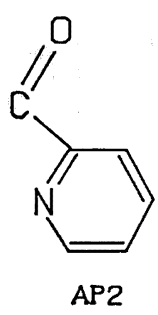

AP2
15) H. Baba, S. Suzuki, T. Takemura, J. Chem. Phys., 50, 2078(1969).
Table 3 Results of configuration analysis for $2,2^{\prime}-$ pyridil in weight percent

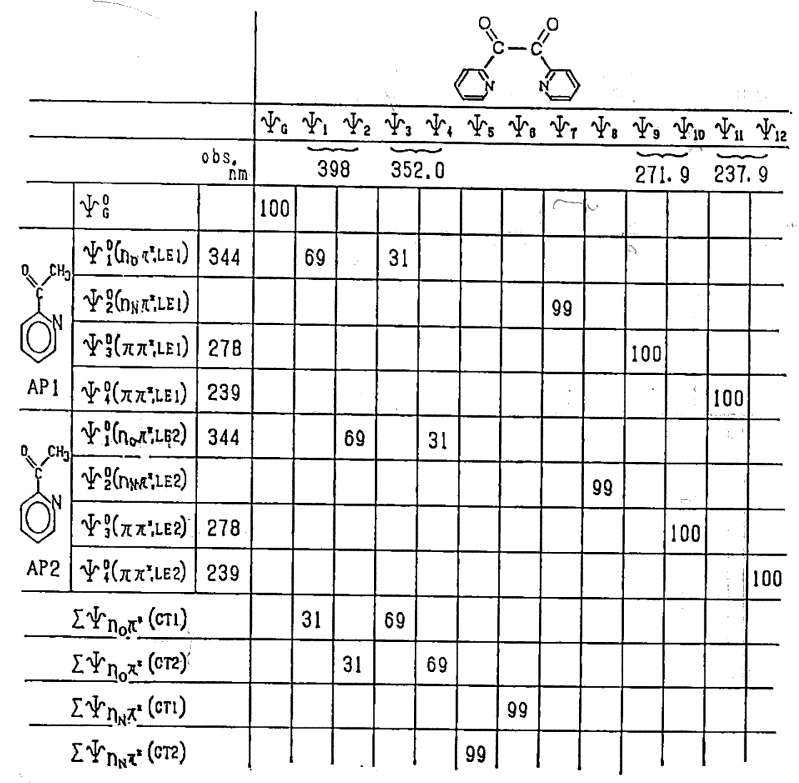

$\Psi_{1}$ : The total wave function of $2,2^{\prime}$-pyridil.

$\Psi_{1}{ }^{0}$ : The total wave function of the reference molecule. (nO(or $\left.{ }_{N} \pi^{*}, L E i\right)$ means a locally excitation from the $n$-orbital of the oxygen or nitrogen atom to the $\pi^{*}$ in $\mathrm{APi} .\left(\pi \pi^{*}, \mathrm{LEi}\right)$ means a $\pi \pi^{*}$ locally excitation in $\mathrm{APi}$.

$\sum \Psi_{\mathrm{no(ON} \text { ) }} \pi^{*}(\mathrm{CT} 1$ (or 2)): The total weight of the charge transfer configurations from the n-orbital of the oxygen or nitrogen atom in AP 1 (or 2) to the $\pi^{*}$ in $\operatorname{AP} 2$ (or AP 1 ).

格にそれぞれ局在化した $\mathrm{n}_{\mathrm{O}} \pi^{*}$ 要移であるとみなすことができ る。なお，この $\mathrm{n}_{\mathrm{O}} \pi^{*}$ 遷移には AP 1 (あるいは AP 2) の酸素 原子の $\mathrm{n}$ 軌道から AP 2（あるいは AP 1) の $\pi^{*}$ 軌道への励起配 置が $31 \%$ 含まれている。 $352.0 \mathrm{~nm}$ にある $\mathrm{n} \pi$ 遷移に対応する 励起状態の波動関数 $\Psi_{3}$ 拈よび $\Psi_{4}$ には AP 1 (あるいは AP 2) の $\mathrm{n}_{0}$ 轨道から AP 2 (あるいはAP 1) の $\pi^{*}$ 轨道への励起配固 が $69 \%$ 寄与している。したがって，この $352.0 \mathrm{~nm}$ にある $\mathrm{n} \pi *$ 帯はこれまで見いだされている $\mathrm{n} \pi *$ 遈移とは異なり, 酸素原子 の $\mathrm{n}$ 軌道から他の骨格の $\pi$ 電子系への分子内 $\mathrm{CT}$ 型の $\mathrm{n} \pi *$ 遷移 によるものである。この分子の場合, カルボニル基の酸素原子の $\mathrm{n}$ 軌道は，下に示すように他の骨格の $\pi$ 軌道と相互作用できるよ らな空間的配置をとっている。ここでの MO 計算では, この $\mathrm{n}$ 軌道と $\pi$ 軌道との間の共鳴積分を無視しているので, 分子内 CT 型の $\mathrm{n} \pi^{*}$ 遷移の強度はゼロになっている。

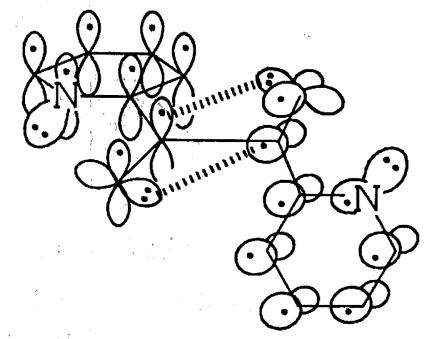


$2,2^{\prime}$ ーピリジルの 271.9 扎よび $237.9 \mathrm{~nm}$ に钼測された $\pi \pi^{*}$ 遷移はいずれも AP 1（または AP 2) に局在化した $\pi \pi^{*}$ 遷移の 重なりによるものである。また, これらの帯は, いずれも2-アセ チルピリジンの $\pi \pi^{*}$ 嗘移の性格をほぼ $100 \%$ 受け継いでいる。 $\Psi_{5} \sim \Psi_{8}$ が関与する遷移は窒素原子の $\mathrm{n}$ 軌道による $\mathrm{n} \pi^{*}$ 遷移
であるが，これらの遷移に対応する帯は，先にも述べたよ5に実 測されていない。しかし， no $\pi^{*}$ 遷移の場合とは異なり, 分子内 CT 型の $\mathrm{n} \pi *$ 遷移が通常の型の $\mathrm{n} \pi^{*}$ 邆移より低エネルギー側に 算出されている。

\section{The Nature of $n \rightarrow \pi^{*}$ Transitions of Di-2-pyridylethanedione}

Toshihiko Hoshi*, Jun Окиво**, Isao Ono, Seiichi Watanabe, Hiroyasu I IOUE***, Tadamitsu S S AKURAI*** and Michio КовауаSHi $* * * *$

Department of Chemistry, College of Science and Engineering, Aoyama Gakuin University; Chitosedai, Setagaya-ku, Tokyo 157 Japan

** Research Institute, Aoyama Gakuin University; Chitosedai, Setagaya-ku, Tokyo 157 Japan

*** Department of Applied Chemistry, Faculty of Technology, Kanagawa

University; Rokkakubashi, Kanagawa-ku, Yokohama-shi 221 Japan

**** Department of Chemistry, Nagaoka University of Technology ;

Kamitomioka, Nagaoka-shi 940-21 Japan

The electronic absorption spectra of di-2-pyridylethanedione (2,2'-pyridil) have been measured in EPA at room temperature and $101 \mathrm{~K}$, and compared with those of benzil. The polarized absorption spectra of 2,2'-pyridil and 2-acetylpyridine have been measured in the stretched PVA film at $101 \mathrm{~K}$, the latter molecule having a half $\pi$-electron framework of the former. It is found that, for instance, the weak band system of $2,2^{\prime}$-pyridil in the wavelength region $320 \sim 430 \mathrm{~nm}$ consists of two electronic transitions, whose $0-0$ bands are at $398 \mathrm{~nm}$ and $352.0 \mathrm{~nm}$. Both electronic bands are assigned as the transitions from the $\mathrm{n}$-orbitals of the oxygen atoms to the $\pi^{*}$-orbitals. The comparison between the observed and calculated splitting values of the two $n \rightarrow \pi^{*}$ transition energies indicates that the $2,2^{\prime}$-pyridil molecule is twisted around the central $\mathrm{C}-\mathrm{C}$ bond by about $80^{\circ}$ in solution. From the configuration analysis, it is found that the $398 \mathrm{~nm}$ band is due to the transition from the n-orbitals of the oxygen atom to the $\pi^{*}$-orbitals in the 2 -acetylpyridine skeleton to which the oxygen atom belongs, and the $352.0 \mathrm{~nm}$ band to the transition from the $\mathrm{n}$-orbitals of oxygen atoms to the $\pi^{*}$-orbital in which the $\mathrm{n}$ - and $\pi^{*}$-orbitals belong to the different 2 -acetylpyridine skeletons. 